\title{
The 1997-98 Summer Rainfall Season in Southern Africa. Part I: Observations
}

\author{
BRADFIELD LyON AND SIMON J. MASON \\ International Research Institute for Climate and Society, The Earth Institute at Columbia University, Palisades, New York
}

(Manuscript received 2 May 2006, in final form 14 November 2006)

\begin{abstract}
Following the onset of the strong El Niño of 1997-98 historical rainfall teleconnection patterns and dynamical model predictions both suggested an enhanced likelihood of drought for southern Africa, but widespread dry conditions failed to materialize. Results from a diagnostic study of NCEP-NCAR reanalysis data are reported here demonstrating how the large- and regional-scale atmospheric circulations during the 1997-98 El Niño differed from previous events. Emphasis is placed on the January-March 1998 season and comparisons with the strong 1982-83 El Niño, although composites of eight events occurring between 1950 and 2000 are also considered. In a companion paper, simulation runs from three atmospheric general circulation models (AGCMs), and forecasts from three fully coupled models are employed to investigate the extent to which the anomalous atmospheric circulation patterns during the 1997-98 El Niño may have been anticipated.

Observational results indicate that the 1997-98 El Niño displayed significant differences from both the 1982-83 episode and the composite event. An unusually strong Angola low, exceptionally high sea surface temperatures (SSTs) in the western Indian and eastern tropical South Atlantic Oceans, and an enhanced northerly moisture flux from the continental interior and the western tropical Indian Ocean all appear to have contributed to more seasonal rainfall in 1997-98 over much of the southern Africa subcontinent than in past El Niño events.
\end{abstract}

\section{Introduction}

The tendency for warm season rainfall in southern Africa to be below average during El Niño events is a well-documented, temporally stable manifestation of the phenomenon (Mason and Goddard 2001; Lindesay and Vogel 1990) with two of the worst regional droughts of the twentieth century associated with the El Niño episodes of 1991-92 and 1982-83 (Rouault and Richard 2003). Thus, expectations of widespread drought across southern Africa were justifiably heightened following the development of the strong 1997-98 El Niño, particularly given that many seasonal climate forecasts made at the time were indicating an enhanced probability of below-average precipitation (Mason et al. 1999; Buizer et al. 2000). In a notable exception to the canonical El Niño rainfall response pattern, widespread drought generally failed to materialize in southern Africa in 1997-98, with seasonal rainfall in many

Corresponding author address: Dr. Bradfield Lyon, International Research Institute for Climate and Society, 61 Route 9W, Palisades, NY 10964.

E-mail: blyon@iri.columbia.edu areas observed to be near or even above average (Richard et al. 2001).

A diagnostic study was undertaken to investigate which aspects of the atmospheric circulation showed significant departures from the typical El Niño response pattern in the 1997-98 event, and the results of this study are reported here and in a companion paper (B. Lyon and S. J. Mason 2006, unpublished manuscript). Observed features of the atmosphere for the 1997-98 episode were compared with both the strong El Niño event of 1982-83 and composite features of eight El Niño events occurring between 1950 and 2000. The primary focus of this study is on the large- and regional-scale atmospheric response to El Niño (and more generally, global SST forcing) as they affect southern Africa rainfall on seasonal time scales, not the synoptic systems whih generated individual rainfall events. This work represents an extension of the investigation by Reason and Jagadheesha (2005), who considered the comparative behavior of recent El Niño events as they affected southern Africa rainfall. In the companion paper, output from three atmospheric general circulation models forced with observed sea surface temperatures for January-March 1998 and predic- 
tions for the same period from three fully coupled ocean-atmosphere models from the Development of a European Multimodel Ensemble System for Seasonal-toInterannual Prediction (DEMETER) project (Palmer et al. 2004) are examined to determine to what extent these departures from the canonical El Niño pattern could have been anticipated.

The general land area of interest is the subcontinent of southern Africa from $15^{\circ} \mathrm{S}$ to the southern coast of South Africa. Annual precipitation in the region is dominated by warm season rainfall (generally OctoberMarch), and, with the exceptions of the far southern and western parts of South Africa, $40 \%$ to more than $80 \%$ of the annual total is typically received between the months of December and March (Richard et al. 2001). The influence of El Niño [and more generally, the El Niño-Southern Oscillation (ENSO) phenomenon] on warm season rainfall is largest in southeastern Africa, typically between the months of December and March (Ropelewski and Halpert 1987; Matarira 1990; Moron et al. 1995; Rocha and Simmonds 1997a,b; Reason et al. 2000; Mason and Tyson 2000; Mason and Goddard 2001), when ENSO events are usually fully developed and summertime circulation systems (including the subtropical jet) in the region have reached their southernmost extent (Lindesay and Vogel 1990; Mason and Jury 1997; Mason and Tyson 2000).

Both tropical and extratropical influences have been associated with seasonal rainfall variability across southern Africa. Atmospheric moisture is transported into the region primarily from over the western Indian Ocean (D'Abreton and Lindesay 1993; D'Abreton and Tyson 1995), but also from the tropical continental interior and, to a more limited extent, the tropical Atlantic (Todd and Washington 1999; Reason and Jagadheesha 2005). Unusually dry summers in southeastern Africa are often associated with negative sea level pressure (SLP) anomalies over the western Indian Ocean, reducing the climatological northeasterly flux of tropical moisture into the region (Mason and Jury 1997; Rocha and Simmonds 1997a,b). Variations in the strength and location of the Angola low, which develops over the southern Africa landmass in summer, affects both moisture transport and the location and formation of tropical-temperate troughs, a major contributor to precipitation (Kuhnel 1989; Todd and Washington 1999; Reason and Mulenga 1999). In the subtropics, zonal moisture flux anomalies are generally more important during the early part of the rainy season (October-December), with meridional fluxes acquiring greater importance later in the season (D'Abreton and Lindesay 1993). During the mature stage of El Niño the climatological region of moisture flux convergence, usually located over subtropical land areas during December-February, typically shifts northeastward, favoring dry conditions over southern Africa and increased rainfall offshore (Lindesay et al. 1986; Mason and Jury 1997; Cook 2000; Reason and Jagadheesha 2005).

In addition to the eastern equatorial Pacific, tropical SST anomalies in the central Indian and eastern South Atlantic Oceans have also been associated with rainfall variations in southern Africa (Mason 1995; Jury 1996; Goddard and Graham 1999; Landman and Mason 1999; Reason 2002), including coastal SST variations associated with interannual variability of the Agulhas and Benguela Currents (Nicholson and Entekhabi 1987; Walker 1990; Mason and Jury 1997). Episodic warming events in the southeast South Atlantic occurring in the northern regions of the Benguela Current system have been linked to enhanced rainfall in Angola and Namibia, and occasionally other parts of southern Africa (Rouault et al. 2003). In the Indian Ocean the largest (negative) correlations with southern Africa rainfall are with SST anomalies located in the west-central part of the basin, even in the absence of El Niño (Mason 1995; Rocha and Simmonds 1997a,b), although this relationship appears to have weakened over the past few decades, possibly as a consequence of upward SST trends in the Indian Ocean basin (Landman and Mason 1999). While SST variations in the tropical Atlantic and Indian Oceans are known to exhibit a lagged relationship with the behavior of ENSO in the tropical Pacific, zonal SST variations across the equatorial Indian Ocean have been related to regional air-sea interactions acting both independently of ENSO (e.g., Saji et al. 1999; Webster et al. 1999) as well as under its influence (Saji and Yamagata 2003; Xie et al. 2002; Loschnigg et al. 2003). The relationship between western Indian Ocean SSTs and southern African rainfall also exhibits significant decadal variability (Reason and Mulenga 1999).

The primary influence of the extratropical atmosphere on southern Africa rainfall is related to the tropospheric stationary wave pattern, which is known to be affected by El Niño (Trenberth 1980; Karoly 1989). Unusually dry conditions during southern Africa summers are often associated with an eastward shift (and weakening) of the climatological upper-level trough, located directly poleward of South Africa (Tyson 1981; Mason and Jury 1997). Such shifts affect extratropical wave interactions with tropical easterly waves and the formation and location of tropical-temperate troughs. A subtropical, longitudinal dipole structure in SST anomalies across the southern Indian Ocean has been 
related to changes in moisture transport into southeastern Africa with below (above) average SSTs in the southwestern (southeastern) part of the basin associated with anomalously dry (wet) conditions (Behera and Yamagata 2001; Reason 2002). An important goal of the current study is to determine to what extent tropical and extratropical influences affected seasonal rainfall in southern Africa during the 1997-98 El Niño.

\section{Data and methodology}

\section{a. Data}

A number of atmospheric fields from the National Centers for Environmental Prediction-National Center for Atmospheric Research (NCEP-NCAR) reanalysis project (Kistler et al. 2001) for the period 1950-2000 were utilized and will be referred to as the atmospheric "observations" in the study. While there are some concerns of data quality in the reanalysis for the Southern Hemisphere, especially prior to the assimilation of satellite information, emphasis will be placed on the El Niño events of 1982-83 and 1997-98, when these data are most reliable. A subset of analyses based separately on pre- and postsatellite period data did not indicate substantially different results from the composites (of all El Niño events) for the full time period. While biases in fields such as moisture transport (Trenberth and Guillemot 1998) and pressure (e.g., Hines et al. 2000) are known to exist in the reanalysis, these effects should not significantly influence the results here that are based on comparisons of anomaly fields. Monthly SST data were obtained from the extended reconstruction of global SST developed by Smith and Reynolds (2003), which are on a $2.0^{\circ} \times 2.0^{\circ}$ latitude-longitude grid. The station-based global precipitation analyses produced at the Climate Research Unit (CRU), University of East Anglia (New et al. 1999, 2000, 2001) were the primary source of monthly rainfall data, which are on a $0.5^{\circ} \times$ $0.5^{\circ}$ latitude-longitude grid. Varying station data input to the CRU dataset over time can affect the local variance in the gridded rainfall amounts, particularly in data sparse regions (New et al. 2000). For southern Africa this effect appears to be most important in Angola and parts of Namibia, but the reliability of the CRU data is deemed to be sufficient for its use in the current study. Merged gauge and satellite estimates of daily rainfall, on a $0.1^{\circ} \times 0.1^{\circ}$ latitude-longitude grid, covering the period January 1995-November 2005, were obtained from the U.S. Climate Prediction Center/Famine Early Warning System dataset. Merged monthly rainfall data for the globe were from the U.S. Climate Prediction Center's Merged Analysis of Precipitation (CMAP: Xie and Arkin 1996), which is on a $2.5^{\circ} \times 2.5^{\circ}$ latitude-longitude grid. The $1961-90$ base period was used to compute climatological mean values for all fields. (All of the data used in the study were accessed online via the IRI Data Library at http:// iridl.ldeo.columbia.edu/.)

\section{b. Methodological approach}

The main season of interest here is January-March (JFM), since it is a period that contributes significantly to the summer rainy season across southern Africa, approximately coincides with the mature phase of El Niño and, as will be shown, is the season during 1997-98 when rainfall departed most significantly from the typical El Niño response. For comparison with the 1997-98 episode, historical El Niño events were identified using a 5-month running average of SST anomalies averaged over the Niño-3.4 region $\left(5^{\circ} \mathrm{S}-5^{\circ} \mathrm{N}, 120^{\circ}-170^{\circ} \mathrm{W}\right)$. An El Niño was included for analysis when this index exceeded $0.5^{\circ} \mathrm{C}$ for at least six consecutive months, had an onset prior to October (the approximate start of the southern Africa rainy season), and remained above $+0.5^{\circ} \mathrm{C}$ at least through March of the year following the onset. Based on this method, eight El Niño events (excluding 1997-98) occurring between 1950 and 2000 were selected for analysis, namely, the JFM seasons of 1958, 1966, 1969, 1973, 1983, 1987, 1992, and 1995. Time series of the evolution of monthly Niño-3.4 SST anomalies for all the El Niño events used are shown in Fig. 1. The figure indicates that, although the 1997-98 event developed more rapidly than the other events during austral fall and winter, by late austral spring the magnitude of the Niño-3.4 SST anomalies were similar to those during the 1982-83 episode, and both events had a similar temporal evolution (in terms of SST variations in the east-central Pacific) from austral summer into the fall. As mentioned, emphasis is placed on comparisons with the 1982-83 event because of data quality issues. However, some of the analyses presented are based on composites, an approach successfully employed in numerous investigations of El Niño (e.g., Rasmusson and Carpenter 1982; Arkin 1982; Karoly 1989; Reason et al. 2000).

\section{Observed conditions in $1997-98$ and past $\mathbf{E I}$ Niño events}

\section{a. Regional rainfall and anomalous moisture fluxes}

The fraction of southern Africa with monthly rainfall less than the lower tercile (tercile classes are defined for each month by ranking rainfall over the 1961-90 base period) is shown in Fig. 2 for both the median of the eight El Niño events and the 1997-98 episode (based on 


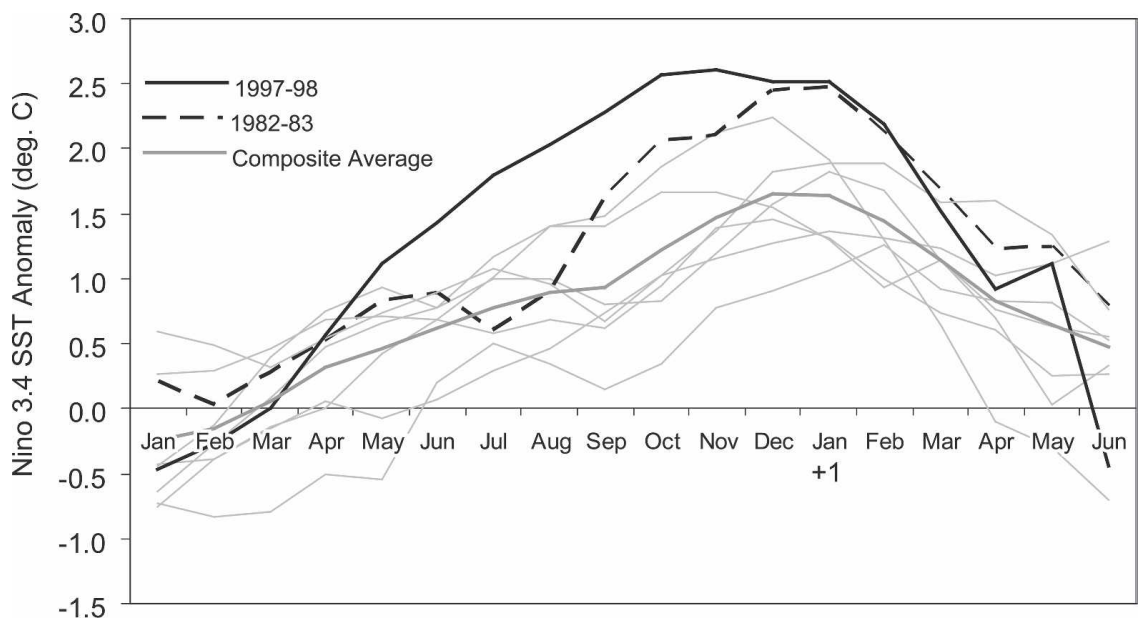

FIG. 1. Time series of monthly SST anomalies averaged over the Niño-3.4 region from January of the onset year of El Niño events used in the study to June of the subsequent year (indicated by the "+1" on the time axis). The bold, solid black (gray) line represents the 1997-98 (composite) El Niño, with the 1982-83 event shown by the bold, dashed gray line. Unit is ${ }^{\circ} \mathrm{C}$.

the CRU data). Figure 2 indicates that the first half of the 1997-98 rainy season (October-December) was similar to the "typical" El Niño response in the region, while conditions were not nearly as dry during the second half, at least on the regional scale. Although the number of rainfall observations incorporated into the CRU product were limited in western parts of the subcontinent for 1997-98 (M. Hulme 2006, personal communication) tending to bias the data toward climatology, the extent of dry conditions in January 1998 was reduced by almost two standard deviations below the median, reflecting a real fluctuation in seasonal climate. An inspection of tropical storm track data from the Joint Typhoon Warning Center and area-averaged

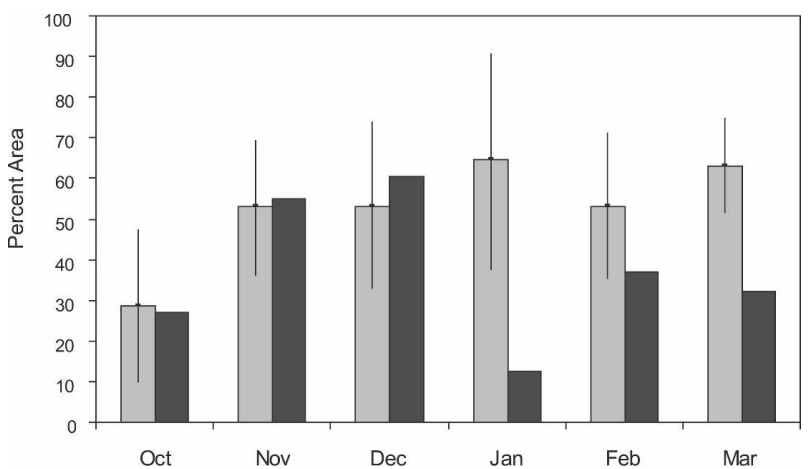

FIG. 2. The percentage of grid points in the southern Africa land region $\left(15^{\circ}-35^{\circ} \mathrm{S}, 12^{\circ}-40^{\circ} \mathrm{E}\right)$ with precipitation in the lowest tercile, by month. Gray bars are the median value of eight El Niño events (vertical lines are \pm one standard deviation), with black bars for the 1997-98 episode. daily rainfall estimates from satellite for the JFM season (not shown) reveal that the above-average rainfall in January 1998 was not the result of tropical storm activity over the southwestern Indian Ocean and the largest rainfall events (in the area average) were not associated with tropical storms at all. Therefore, the monthly and seasonal rainfall anomalies in JFM 1998 were not simply the result of a few extreme rainfall events.

The geographical distribution of rainfall across southern Africa for JFM 1998 is shown in Fig. 3a, again in tercile classes, along with the anomalous vertically integrated $(850-300 \mathrm{hPa})$ moisture flux and its divergence computed from the reanalysis. A similar plot for JFM 1983 is shown in Fig. 3b. A comparison of these plots clearly indicates that during JFM 1998 rainfall amounts in the lowest tercile were not as widespread as in 1983 in southern Africa with several areas experiencing rainfall in the upper tercile in JFM 1998. Not surprisingly, the anomalous integrated moisture flux in Figs. $3 \mathrm{a}$ and $3 \mathrm{~b}$ shows marked differences between these events as well. The anomalous easterly flux of moisture over the equatorial Indian Ocean (about $0^{\circ}$ $5^{\circ} \mathrm{S}$ ) in JFM 1983 was clearly enhanced and extended farther south during JFM 1998, providing an abundant moisture source for the heavy rainfall in eastern Africa (which were exceptionally heavy during the short rains across Kenya in late 1997). The anomalous northerly component to the moisture flux associated with the recurving of this easterly flow was enhanced in 1998 relative to 1983 and extended farther south, consistent with the enhanced rainfall over Tanzania, northern Mozam- 

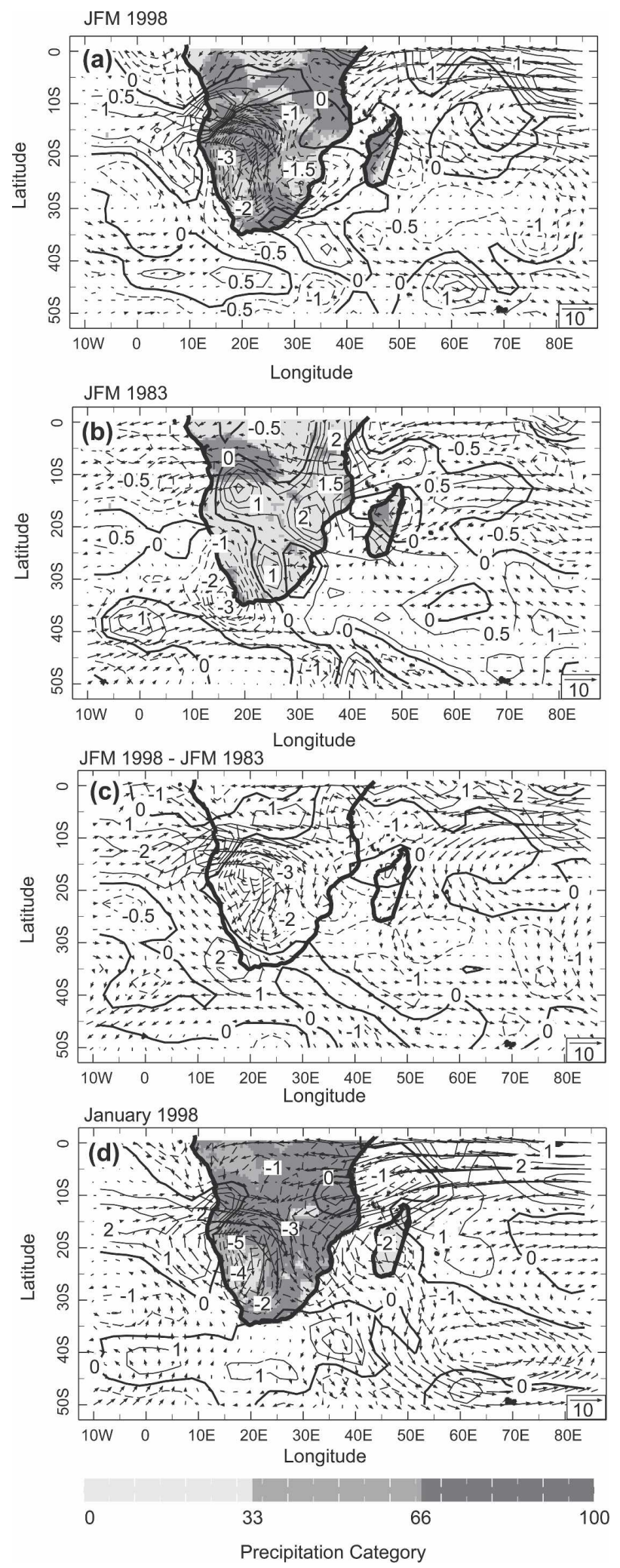

Precipitation Category bique, and western Madagascar. In JFM 1983 convergence of the anomalous moisture flux occurred to the east of Madagascar, resulting from a weakened subtropical high over the southwestern Indian Ocean and the anomalous westerly flux from the Tropics farther north, a pattern similar to the composite El Niño (not shown). In JFM 1998 this convergence zone was again present but extended farther to the south and west, as seen more clearly in Fig. 3c, which displays the difference in the anomalous moisture flux between JFM 1998 and 1983. A large area of convergence of the anomalous moisture flux is seen over the southern Africa subcontinent in JFM 1998, where divergence and anomalously dry conditions occurred in 1983 and in the composite El Niño (not shown). Moisture flux divergence was enhanced in northern tropical land areas (north of about $15^{\circ}$ S) in JFM 1998, associated with enhanced dry conditions there.

During JFM 1998 the Angola low was unusually strong relative to 1983 , and farther south the predominantly westerly subtropical moisture flux in JFM 1983 (south of roughly $30^{\circ} \mathrm{S}$ ) developed a significant southerly component in 1998 west of the subcontinent, reducing the advection of drier air from over the South Atlantic into subtropical land areas in 1998, a feature generally associated with anomalously dry conditions in southern Africa (Mason and Jury 1997; D'Abreton and Lindesay 1993). The unusually strong Angola low in 1998 also contributed to an enhanced northerly moisture flux from the tropical continental interior, and to a smaller extent from the equatorial eastern tropical Atlantic, conditions more favorable for rainfall in southern Africa (Reason and Jagadheesha 2005). During the month of January 1998 (Fig. 3d), when rainfall departed most significantly from the composite El Niño, convergence of the anomalous tropical moisture flux extended from over the western Indian Ocean southward to the extratropics south of Madagascar.

\section{b. Anomalous stationary wave patterns}

On the near-global scale, Fig. 4a displays standardized anomalies of the JFM 1998 850-hPa streamfunction for the Tropics and Southern Hemisphere, with the

$\leftarrow$

FIG. 3. Vertically integrated (850-300 hPa) moisture flux anomalies (vectors, units: $\mathrm{kg} \mathrm{s}^{-3} \times 10^{2}$ ) and their divergence (contours, units: $\mathrm{kg} \mathrm{m}^{-1} \mathrm{~s}^{-3} \times 10^{-6}$ ) with precipitation, in tercile classes, represented by shading: (a) JFM 1998, (b) JFM 1983, (c) their difference (1998 minus 1983, precipitation field excluded), and (d) January 1998. Vector scale shown in lower right of (a)-(d). The contour interval for divergence is 0.5 in (a) and (b) and 1 in (c) and (d). 

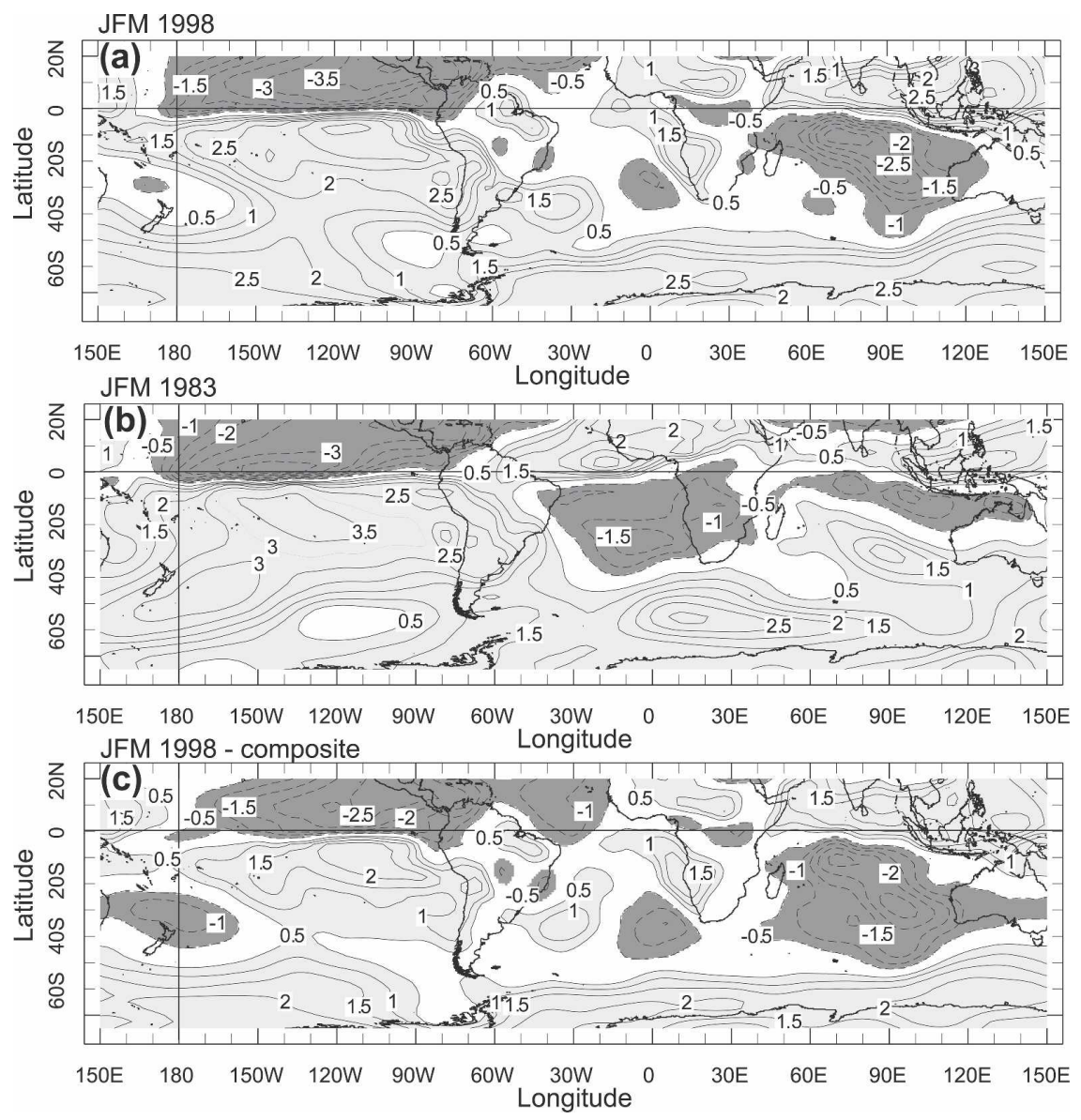

FIG. 4. Standardized anomalous $850-\mathrm{hPa}$ streamfunction (dimensionless) in the reanalysis for (a) JFM 1998, (b) JFM 1983, and (c) JFM 1998 minus composite. Contour interval is 0.5; the zero contour is omitted. Values exceeding \pm 0.5 standard deviations from the mean are shaded.

same field for JFM 1983 plotted in Fig. 4b and the standardized difference between JFM 1998 and the composite El Niño in Fig. 4c. Since the total moisture flux in the Tropics is dominated by its rotational, stationary component (Chen 1985; D'Abreton and Tyson 1995) seasonal average, low-level streamfunction anomalies should capture the salient aspects of the atmospheric circulation associated with that transport during El Niño. In JFM 1998 a large, anomalous anticyclonic circulation (negative streamfunction anomaly) was located over the central Indian Ocean, centered considerably west of its 1983 (and composite, not shown) counterpart and having much greater meridional extent. This feature is consistent with the enhanced easterly moisture flux over the tropical Indian Ocean in JFM 1998 (and on its eastern flank, the westward shift appears to have contributed in the failure of drought developing in northern Australia that season, which often occurs during El Niño events). Positive (cy- clonic) streamfunction anomalies over the subtropical central Indian Ocean to the west of Australia in 1983 were observed in late 1997 (not shown) but were noticeably absent in JFM 1998 when they were confined to the extratropics well to the south. Anomalous subtropical westerlies associated with the positive $850-\mathrm{hPa}$ streamfunction anomalies near and to the south of South Africa in JFM 1983 also show a southward shift in 1998. An enhanced Angola low in JFM 1998 is in stark contrast with the anticyclonic anomalies across southern Africa and the subtropical South Atlantic in JFM 1983, consistent with the findings of Reason and Jagadheesha (2005). Compared with the composite El Niño (Fig. 4c), the enhanced Angola low observed in JFM 1998 appears to be part of an anomalous wave pattern that extends across the western subtropical South Atlantic toward southern Africa, a point addressed in further detail below. The streamfunction anomaly pattern over the east-central tropical Pacific in 

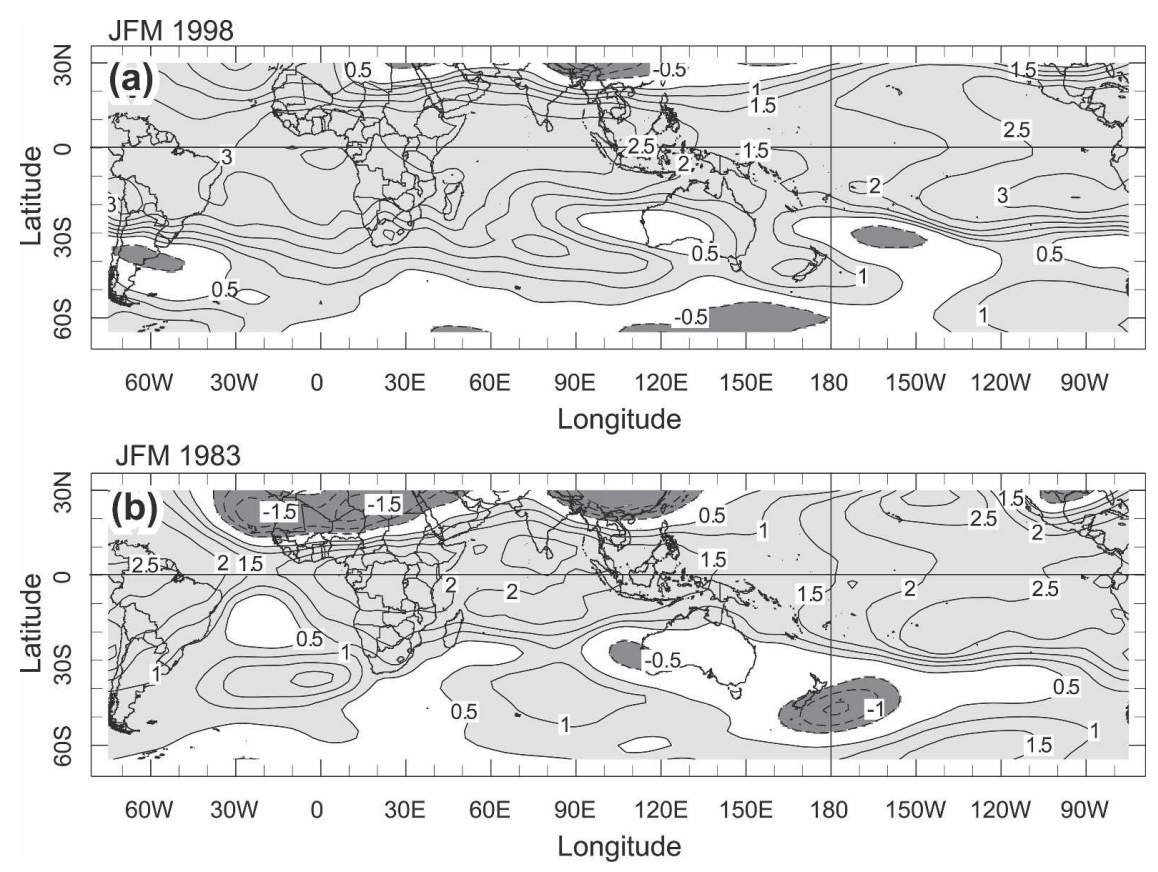

FIG. 5. Standardized tropospheric average (850-200 hPa) temperature anomaly (dimensionless) for (a) JFM 1998, and (b) JFM 1983. Shading indicates values exceeding \pm 0.5 standard deviations from the mean. Contour interval is 0.5 ; the zero contour is omitted.

JFM 1998 relative to the composite El Niño indicates an intensification of the anomalous, twin cyclonic circulations that straddle the equator during El Niño events.

The southward shift in the anomalous westerlies south of South Africa during JFM 1998 compared with JFM 1983 (and the composite) is consistent with the significantly enhanced tropical warming during the former year, as seen in Fig. 5, which displays the standardized 850-200-hPa average temperature anomaly for the two seasons. Temperature anomalies exceeding three standard deviations extended from the deep Tropics southward into southern Africa in JFM 1998 (Fig. 5a) with an enhanced southward-displaced anomalous meridional temperature gradient compared with $1983 .^{1}$ While the heating of the tropical troposphere, which occurs in association with El Niño events (e.g., Sobel et al. 2002), generally increases the atmospheric static stability across the Tropics (Chiang and Sobel 2002), regional factors can offset this stabilizing effect, which in southern Africa in JFM 1998 included changes in the low-level atmospheric circulation rela-

\footnotetext{
${ }^{1}$ The volcanic eruption of El Chichón in April 1982 was likely an important contributor to the generally lower tropical tropospheric temperature anomalies during the El Niño of 1982-83 relative to $1997-98$.
}

tive to 1983 (and the composite El Niño), resulting in an enhanced moisture flux into the region. The increased rainfall in southern Africa in 1998 relative to 1983 would, of course, itself contribute to higher tropospheric temperatures locally due to a relative increase in latent heat release. The relatively cold tropospheric temperatures over North Africa in JFM 1983 are related, at least in part, to a persistent "split flow" pattern over the North Atlantic that year, with an anomalous midlatitude ridge associated with cold air advection into North Africa from Europe and an anomalous subtropical trough located off the west African coast (not shown). To examine differences in the upper-level stationary wave pattern, Figs. $6 \mathrm{a}$ and $6 \mathrm{~b}$ display standardized anomalies of the $200-\mathrm{hPa}$ geopotential height departure from the zonal mean for JFM of 1998 and 1983. The difference between JFM 1998 and the composite El Niño is shown in Fig. 6c, with the anomalous 200-hPa stationary wave pattern for the composite El Niño shown in Fig. 6d. As mentioned, heating of the tropical troposphere during El Niño events generally increases $200-\mathrm{hPa}$ geopotential heights across the Tropics; subtracting the zonal mean value at the latitude of each grid point emphasizes longitudinal asymmetries in this effect. In the Tropics, anomalies in this field generally reverse sign between the lower and upper troposphere, which is typical of forcing by diabatic heating anomalies associated with 

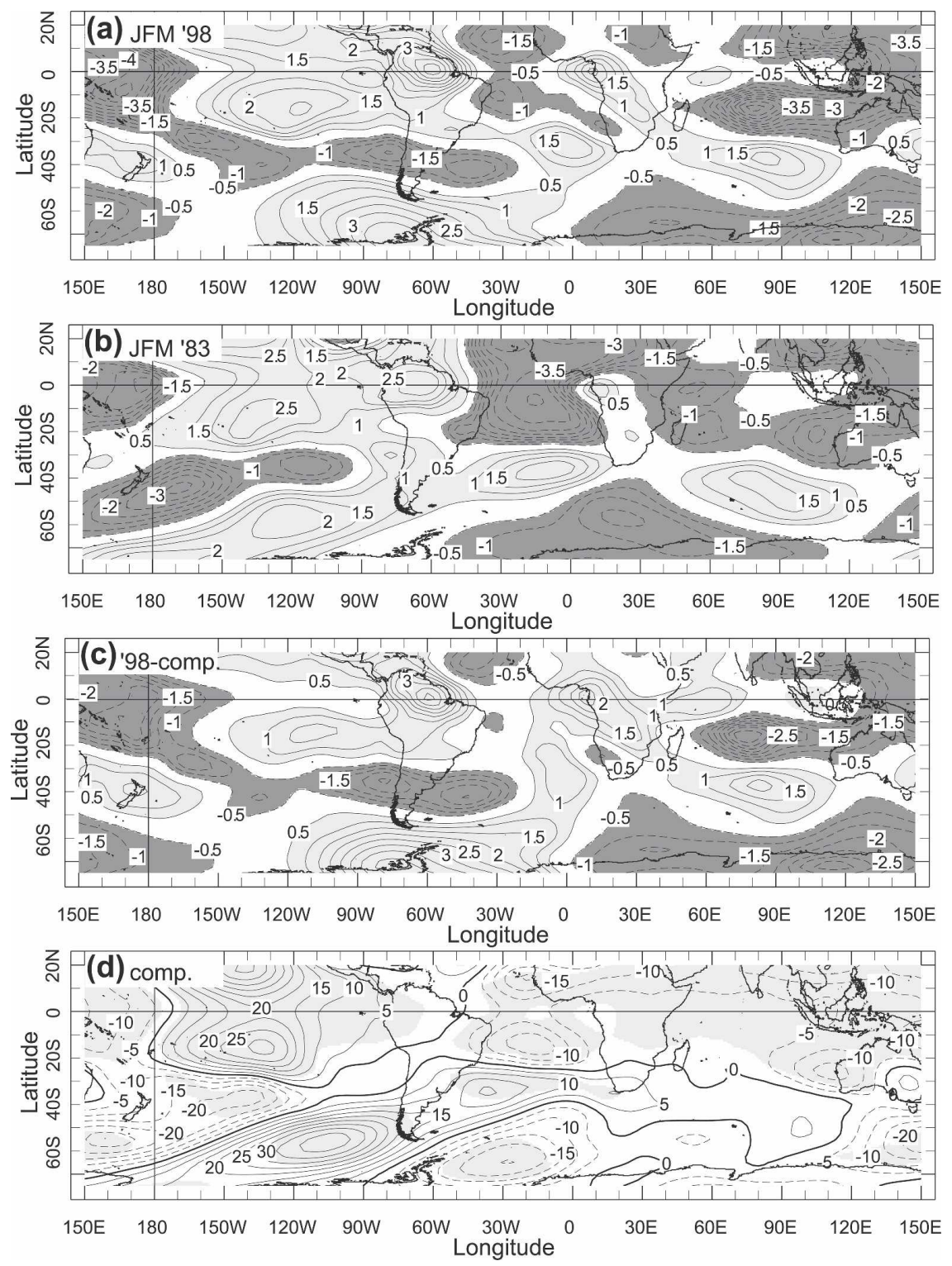

FIG. 6. Anomalous 200-hPa stationary waves showing standardized anomalies (a) for JFM 1998 and (b) for JFM 1983; (c) standardized difference between JFM 1998 and the composite El Niño; and (d) anomaly values (not standardized) for the composite El Niño. Values in plots (a)-(c) are dimensionless with shading showing anomalies exceeding \pm 0.5 standard deviations. In plot (d) the units are gpm with shading indicating anomalies that are statistically significant at or above the $90 \%$ confidence level based on a $t$ test.

spatial shifts in rainfall patterns. In the extratropics, the vertical structure of this anomaly field is nearly equivalent barotropic (e.g., Karoly 1989).

In the Eastern Hemisphere of the Tropics, Fig. 6a indicates large negative anomalies over the central Indian Ocean in JFM 1998, approximately collocated with the anomalous low-level anticyclonic circulation in this region described above (cf. Fig. 4a). Over the eastern South Pacific and South Atlantic Oceans, the anoma- lous stationary wave pattern in JFM 1998 is notably different from that for 1983 and the composite El Niño. In the composite (Fig. 6d), a positive height anomaly centered over the eastern South Pacific near $60^{\circ} \mathrm{S}$, $120^{\circ} \mathrm{W}$ is flanked by negative anomalies to its west and east, forming what is often called the Pacific-South American (PSA) pattern (Mo and Ghil 1987; Mo and Paegle 2001). In JFM 1998 the positive anomaly center in the extratropical South Pacific is shifted substantially 


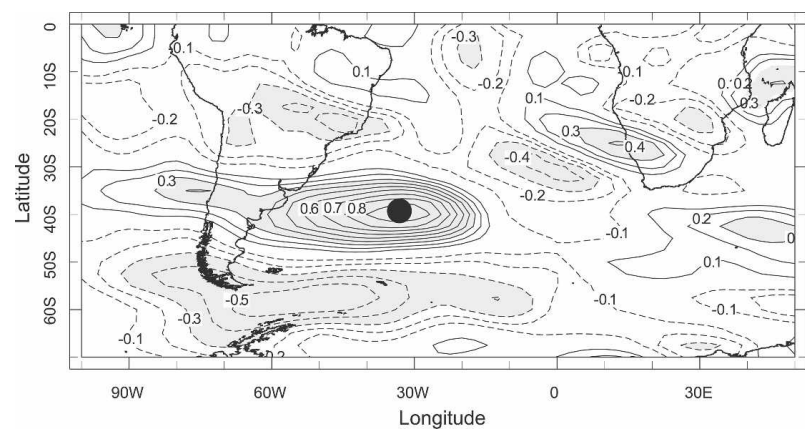

FIG. 7. Correlation between the $200-\mathrm{hPa}$ anomalous stationary wave absolute vorticity averaged at $40^{\circ} \mathrm{S}, 30^{\circ}-40^{\circ} \mathrm{W}$ (centered on the black dot in the figure) with all surrounding grid points for JFM seasons 1950-2000. Shading indicates values that are statistically significant at or above the $95 \%$ confidence level. Contour interval is 0.1 ; the zero contour is omitted.

eastward and to the south of its composite location, to near $70^{\circ} \mathrm{S}, 80^{\circ} \mathrm{W}$. The negative height anomalies to the east of this feature are also displaced to the east of their composite location in JFM 1998. In sharp contrast to JFM 1983 and the composite El Niño, positive height anomalies in JFM 1998 are observed in the vicinity of New Zealand, and a zonally elongated band of negative height anomalies extends across central South America into the western South Atlantic.

Downstream of this western South Atlantic negative height anomaly (centered near $40^{\circ} \mathrm{S}, 40^{\circ} \mathrm{W}$ ) the $200-\mathrm{hPa}$ anomalous stationary wave pattern in JFM 1998 is again suggestive of a wave train that extends across the South Atlantic into southern Africa. Evidence for a generally similar wave pattern, based on both observational and model data, has been reported previously (e.g., Berbery et al. 1992; Hoskins and Ambrizzi 1993; Ambrizzi and Hoskins 1997). While a comprehensive description of this wave pattern goes beyond the scope of the current study, evidence for its viability as a wave train is provided in Fig. 7 showing the correlation between JFM 200-hPa anomalous stationary wave absolute vorticity (i.e., departures from the zonal mean) averaged over the western South Atlantic $\left(35^{\circ}-40^{\circ} \mathrm{S}, 30^{\circ}\right.$ $40^{\circ} \mathrm{W}$ ) and all other grid points based on reanalysis data for the period $1950-2006 .^{2}$ The statistically significant correlation pattern in Fig. 7 shows similarities to the anomalous stationary wave pattern shown in Fig. 6a for JFM 1998 (as well as the difference between JFM 1998 and the composite El Niño; Fig. 6c), suggesting that the anomalous Angola low observed in 1998 may have been, at least in part, influenced by remote atmospheric

\footnotetext{
${ }^{2}$ Omitting data for JFM 1998 had very little effect on the overall correlation pattern shown in Fig. 7.
}

forcing. For example, Colberg et al. (2004) have shown that anomalous sea level pressure and SSTs in the southeastern South Atlantic during El Niño are associated with large-scale atmospheric circulation anomalies likely related to the PSA pattern, with anomalously high pressure typically located off the west coast of the southern Africa subcontinent during the JFM season. Since the PSA pattern is highly correlated with the Southern Oscillation index (e.g., Karoly 1989; Mo 2000), the departure of the anomalous stationary wave pattern across the South Atlantic in JFM 1998 from the more typical PSA pattern, with the suggestion of a wave train across the region into southern Africa and an enhanced Angola low, may be an important departure from the composite El Niño as it affected southern Africa rainfall in 1998.

Detailed comparisons of the second half of the southern Africa rainy season (i.e., JFM) with the first half are beyond the scope of the current study, some limited insight is provided, however, in Fig. 8, which displays the 200-hPa anomalous stationary wave pattern (departure of geopotential heights from their zonal averages) for the period October-December (OND) 1997, OND 1982, and OND for the composite El Niño. As was shown in Fig. 2, the first part of the 1997-98 rainy season in southern Africa was similar to the behavior of past El Niño events (including 1982-83), with belowaverage October-December rainfall observed at several locations. Figures $8 \mathrm{a}$ and $8 \mathrm{~b}$ are consistent with this observation, with the anomalous stationary wave patterns for OND 1997 and 1982 being qualitatively similar over the South Atlantic eastward to the Indian Ocean, with an anomalous ridge over southern Africa somewhat stronger in 1982 (and in the composite) than in 1997. The largest differences in the anomalous stationary waves therefore appear to have developed during the second half of the rainy season, in JFM.

\section{c. Large-scale divergent wind field}

Figures $9 \mathrm{a}$ and $9 \mathrm{~b}$ indicate the anomalous $200-\mathrm{hPa}$ velocity potential and corresponding divergent component of the wind in the reanalysis for JFM 1998 and 1983, respectively. In the Eastern Hemisphere during JFM 1983 (Fig. 9b) positive velocity potential anomalies and associated upper-level convergence (implied subsidence) were centered over the Maritime Continent region, as expected during El Niño. Farther west, upper-level divergence over the central equatorial Indian Ocean in JFM 1983 is associated with anomalous upward motion there (and increased rainfall based on satellite data, not shown), while an elongated zone of upper-level convergence and subsidence was centered over southeastern southern Africa. By contrast, during 

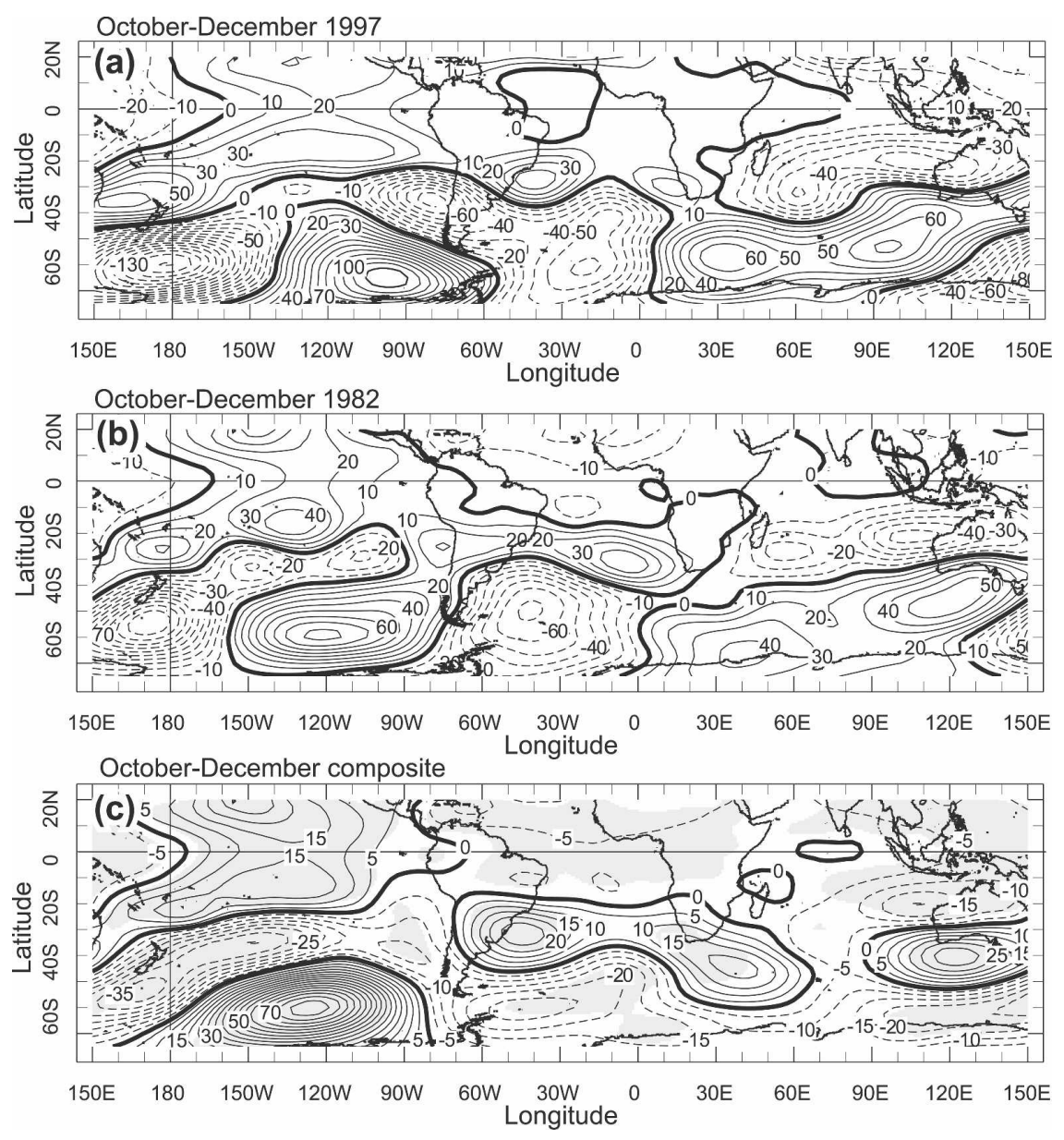

FIG. 8. Anomalous OND 200-hPa stationary wave patterns (units: gpm) for (a) 1997, (b) 1982, and (c) the composite El Niño. Shading in (c) indicates values statistically significant at or above the $90 \%$ confidence level based on a $t$ test.

JFM 1998 the anomalous velocity potential field over Africa was dominated by upper-level divergence centered off the east coast of equatorial Africa, in association with the heavy rainfall there. Anomalous upperlevel convergence (and subsidence) over the central Indian Ocean occurred in JFM 1998, representing a westward extension of this condition over the Maritime Continent observed in 1983. Thus, there was a significant shift in the anomalous Walker-type circulation between tropical Africa and the central Indian Ocean in JFM 1998, with anomalous ascent in the latter region shifted roughly $30^{\circ} \mathrm{W}$ of its 1983 (and composite, not shown) location. Anomalous descent and unusually dry conditions occurred over the central Indian Ocean in JFM 1998 where there was ascending motion in 1983. These features are consistent with the zonal gradient in SST conditions in the Indian Ocean and the enhanced, low-level anticyclonic circulation over the central Indian Ocean in 1998 mentioned previously. Over the eastern tropical Pacific, the center of an elongated region of anomalous upper-level divergence seen in JFM 1983 was of comparable magnitude but displaced slightly to the east in 1998.

\section{d. SST anomalies}

Finally, Fig. 10 displays standardized SST anomalies for JFM of 1998 and 1983 and their difference, as well as the difference between 1998 and the composite El Niño. In the tropical Indian Ocean the largest positive SST anomalies are confined primarily to the eastern part of the basin during JFM 1983. In the eastern equatorial Pacific SST anomalies were of similar magnitude during both the 1998 and 1983 El Niño events, with the largest differences between these events, and between 1998 and the composite El Niño, in the far eastern part of the basin (Figs. 10c and 10d). SSTs were generally much higher in the tropical Atlantic in JFM 1998 compared with 1983 and the composite, particularly in the 

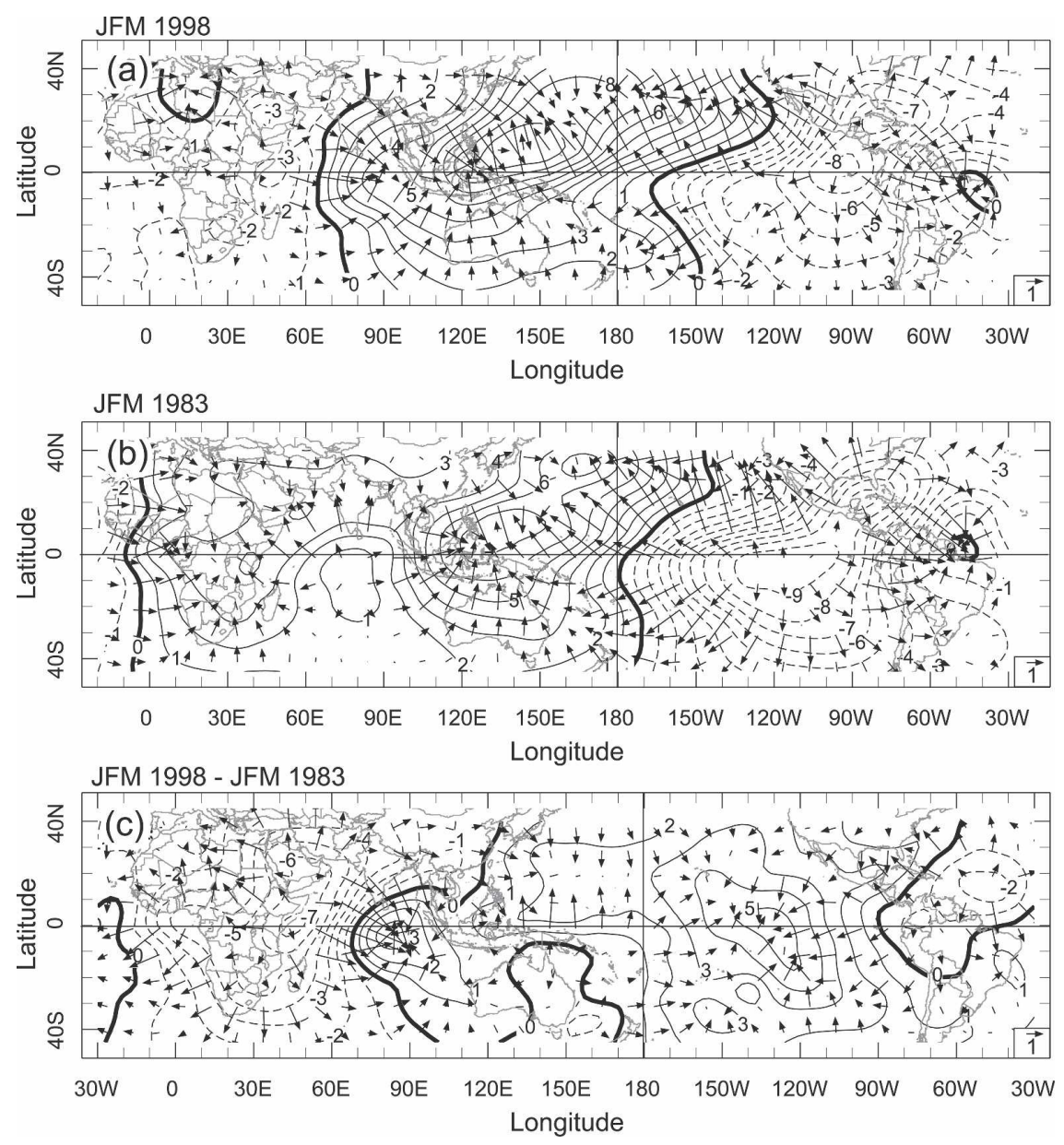

FIG. 9. Anomalous $200-\mathrm{hPa}$ velocity potential (contours, units: $\mathrm{m}^{2} \mathrm{~s}^{-1} \times 10^{6}$ ) and divergent wind component (vectors, units: $\mathrm{m} \mathrm{s}^{-1} \times 10^{1}$ ) in the reanalysis for (a) JFM 1998, (b) JFM 1983, and (c) the difference in anomalous values JFM 1998 minus JFM 1983. Contour interval is 1 for all plots.

Guinea Basin. Reason and Jagadheesha (2005) have suggested that the combination of higher SSTs and the anomalous Angola low may have contributed to increased evaporation and enhanced moisture flux into southern Africa in 1998. In the vicinity of southern Africa, negative SST anomalies in JFM 1983 were located in the subtropical southeastern South Atlantic, consistent with the enhanced low-level westerlies there (cf. Fig. 4b). By contrast, during JFM 1998 the largest tropical SST anomalies in the Indian Ocean were located in the far western part of the basin, near and off the coast of eastern Africa, where they exceeded three standard deviations from the mean. Webster et al. (1999) attributed the large Indian Ocean SST anomalies during the 1997-98 El Niño to ocean-atmosphere coupling in the basin, not simply to an enhanced response to the anomalous SST conditions in the equatorial Pacific. Subtropical SSTs in the southeastern South Atlantic southwest of the subcontinent were somewhat cooler during JFM 1998, again consistent with the low-level anticyclone being weaker in 1998 than in JFM 1983.

Overall, conditions both favorable and unfavorable for rainfall in southern Africa were present in JFM 1998. An anomalous anticyclonic circulation over the central Indian Ocean, having greater intensity and spatial extent and shifted westward of its 1983 and composite counterparts, was associated with a significantly enhanced moisture flux into tropical East Africa in 1998. On the southern flank of this feature, however, westerly wind anomalies in the subtropics east of Madagascar reduced the climatological flux of moisture into southeastern southern Africa. The westward shift of this anomalous anticyclone (relative to both JFM 1983 and composite El Niño conditions) appears to be associated with the very high SSTs in the western Indian Ocean, resulting in a similar westward shift in the 

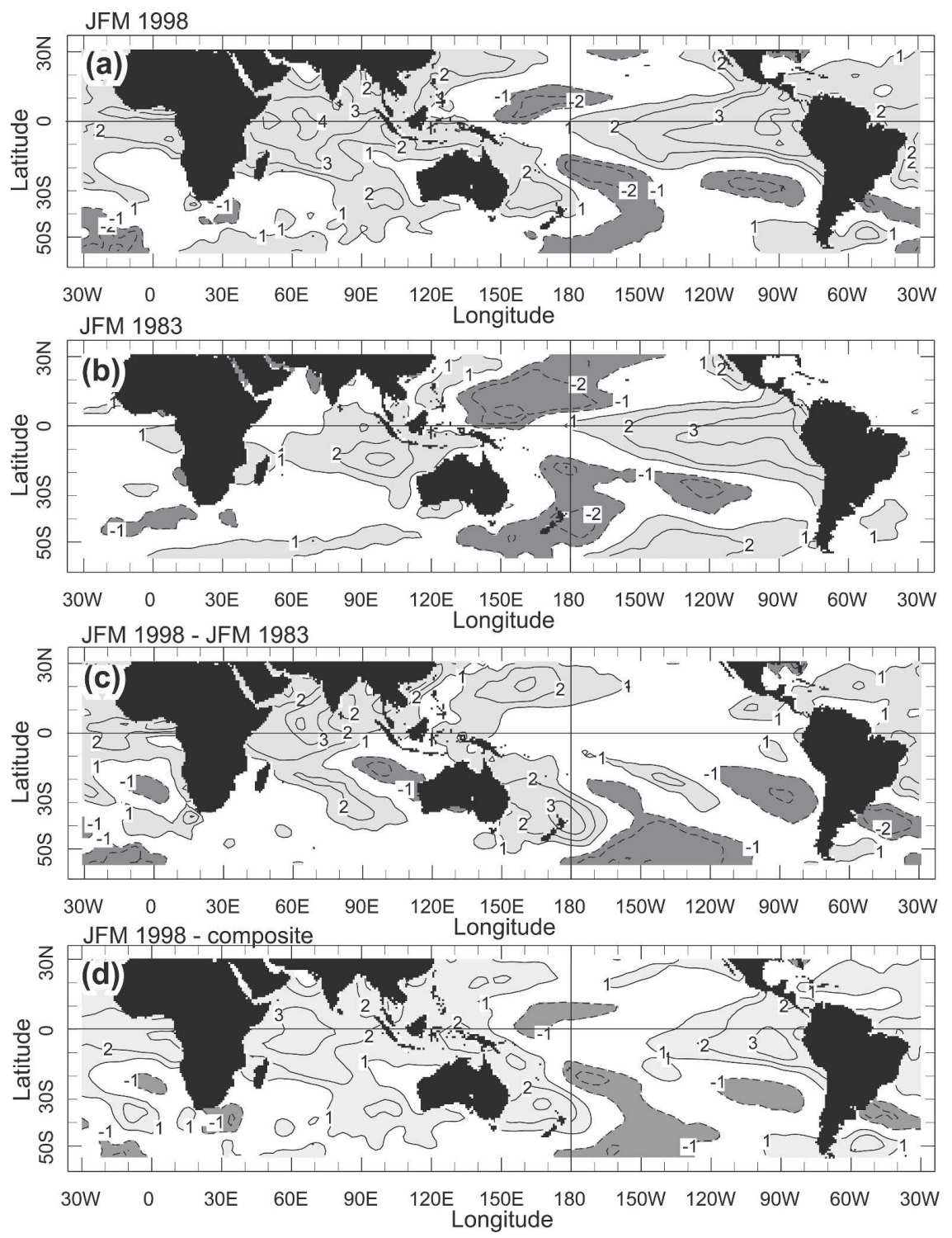

FIG. 10. Standardized SST anomalies (dimensionless) for (a) JFM 1998 and (b) JFM 1983, standardized difference in anomalies, (c) JFM 1998 minus JFM 1983, and (d) differences between JFM 1998 and the composite El Niño. Contour interval is 1 with shading for anomalies exceeding \pm one standard deviation from the mean; the zero contour is omitted.

anomalous Walker circulation over the Indian Ocean with anomalous ascent (descent) over the western (central) part of the basin. Unlike the 1983 event and the composite El Niño, during JFM 1998 an unusually strong Angola low led to an increased moisture flux mainly from the tropical continental interior southward into subtropical southern Africa (Reason and Jagadheesha 2005). Departures in the anomalous stationary wave pattern across the South Atlantic in JFM 1998 relative to 1983 and the composite El Niño suggests that this feature may have been associated with a larger-scale, anomalous circulation pattern. In addition, while present in the OND 1997 average streamfunction field, the anomalous low-level cyclonic circulation, which usually develops southeast of Madagascar, was absent during JFM 1998. This cyclonic circulation combined with the anomalous anticyclone to its north typically results in the convergence of the anomalous moisture flux extending from roughly northern Madagascar southeastward over the western Indian Ocean, as observed in JFM 1983. In JFM 1998 this convergence zone was located south of its usual position during El Niño that, combined with the enhanced Angola low, allowed for the southerly transport of tropical moisture from 
over the western Indian Ocean into southern Africa, a transport especially pronounced during January of 1998. This tropical flux is important since climatologically the western Indian Ocean is the primary source of late summer moisture for southern Africa rainfall (D'Abreton and Tyson 1995; Reason and Jagadheesha 2005). As the anomalous anticyclonic circulation over the Indian Ocean weakened during February and March of 1998 (not shown), it appears that the role of this moisture source was reduced, although the anomalous Angola low continued to advect moisture into the southern Africa subcontinent from the tropical continental interior, supporting more rainfall than typically occurs during El Niño episodes.

\section{Summary and conclusions}

Several departures in rainfall response over southern Africa and related regional and large-scale atmospheric circulations occurred during JFM 1998 relative to the 1982-83 and the composite El Niño. While El Niño is known to exert a modulating effect on southern Africa summer season rainfall, other factors of both tropical and extratropical origin also play a role in its variability. Internal variations of the extratropical atmospheric circulation (largely unpredictable on seasonal time scales), for example, can affect the stationary wave and precipitation patterns over the southern Africa subcontinent so as to oppose the canonical ENSO signal. Indeed, correlations between southern Africa rainfall and Niño-3.4 SST anomalies (using the CRU data, not shown) indicate the latter account statistically for at most about $25 \%$ of interannual rainfall variability during JFM. Given the observed differences in atmospheric and SST conditions for JFM between 1998 and 1983 (and more generally, the composite El Niño) an immediate question to ask is: To what extent were these differences at least potentially predictable?

The differences in tropical SST anomaly patterns in JFM between 1998 and 1983 represent one possible forcing mechanism for the contrasting atmospheric conditions during these events. Modeling studies have shown that the SST anomalies in the tropical Indian Ocean during 1998 were essential to generating the unusually wet conditions across eastern equatorial Africa that year (Su et al. 2001; Latif et al. 1999), and the importance of the Indian Ocean in affecting eastern and southern Africa rainfall was stressed more generally in the modeling study of Goddard and Graham (1999) and the observational analysis of Black et al. (2003). In Part II of this study (B. Lyon and S. J. Mason 2006, unpublished manuscript) these influences on southern Africa rainfall during the 1997-98 El Niño are examined through analysis of simulation runs from three different AGCMs and forecasts generated from three fully coupled models. The use of coupled models also allows for an evaluation of the extent to which they captured the strong warming of the western Indian Ocean during the 1997-98 El Niño.

In summary, data from the NCEP-NCAR reanalysis has been employed to document several important features of the atmospheric circulation associated with the relatively wet JFM 1998 rainy season in southern Africa. Through comparisons with previous El Niño events, circulation anomalies of differing characteristic spatial scales were identified as being of importance to the enhanced rainfall in 1998. On the regional scale, these anomalies included an unusually strong Angola low and an enhanced moisture flux largely from the tropical continental interior, confirming the results of Reason and Jagadheesha (2005). On the large scale, the stationary wave pattern over the South Atlantic departed substantially from the composite El Niño and a significant longitudinal shift in the ascending and descending branches of the anomalous Walker circulation over the Indian Ocean was identified, along with a significant westward shift in the location of an anomalous low-level anticyclonic circulation usually centered near the west coast of Australia during El Niño. This latter feature affected the contemporaneous large-scale anomalous moisture flux pattern across the Indian Ocean basin, including a substantial enhancement of moisture transport into tropical eastern Africa and, to a lesser extent, southern Africa. An assessment of the extent to which these departures from the canonical El Niño response could have been anticipated is considered in a companion paper based on analysis of output from both AGCM model simulations and coupled model forecasts.

Acknowledgments. The authors thank Tony Barnston, Alessandra Giannini, and three anonymous reviewers for their comments and suggestions on an earlier version of this manuscript. This paper is funded in part by a grant from the National Oceanic and Atmospheric Administration, NA050AR4311004. The views expressed herein are those of the authors and do not necessarily reflect the views of NOAA or any of its subagencies.

\section{REFERENCES}

Ambrizzi, T., and B. J. Hoskins, 1997: Stationary Rossby-wave propagation in a baroclinic atmosphere. Quart. J. Roy. Meteor. Soc., 123, 919-928.

Arkin, P. A., 1982: The relationship between interannual variability in the $200 \mathrm{mb}$ tropical wind field and the Southern Oscillation. Mon. Wea. Rev., 110, 1393-1404. 
Behera, S. K., and T. Yamagata, 2001: Subtropical SST dipole events in the southern Indian Ocean. Geophys. Res. Lett., 28, 327-330.

Berbery, E. H., J. N. Paegle, and J. D. Horel, 1992: Wavelike Southern Hemisphere extratropical teleconnections. J. Atmos. Sci., 49, 155-177.

Black, E., J. Slingo, and K. R. Sperber, 2003: An observational study of the relationship between excessively strong short rains in coastal East Africa and Indian Ocean SST. Mon. Wea. Rev., 131, 74-94.

Buizer, J. L., J. Foster, and D. Lund, 2000: Global impacts and regional actions: Preparing for the 1997/98 El Niño. Bull. Amer. Meteor. Soc., 81, 2121-2139.

Chen, T.-C., 1985: Global water vapor flux and maintenance during FGGE. Mon. Wea. Rev., 113, 1801-1819.

Chiang, J. C. H., and A. H. Sobel, 2002: Tropical tropospheric temperature variations caused by ENSO and their influence on the remote tropical climate. J. Climate, 15, 2616-2631.

Colberg, F., C. J. C. Reason, and K. Rodgers, 2004: South Atlantic response to El Niño-Southern Oscillation induced climate variability in an ocean general circulation model. J. Geophys. Res., 109, C12015, doi:10.1029/2004JC002301.

Cook, K. H., 2000: The South Indian convergence zone and interannual rainfall variability over southern Africa. J. Climate, 13, 3789-3804.

D'Abreton, P. C. D., and J. A. Lindesay, 1993: Water vapor transport over southern Africa during wet and dry early and late summer months. Int. J. Climatol., 13, 151-170.

— vapour transport over southern Africa during wet and dry conditions. Meteor. Atmos. Phys., 55, 47-59.

Goddard, L., and N. E. Graham, 1999: Importance of the Indian Ocean for simulating rainfall anomalies over eastern and southern Africa. J. Geophys. Res., 104, 19 099-19 116.

Hines, K. M., D. H. Bromwich, and G. J. Marshall, 2000: Artificial surface pressure trends in the NCEP-NCAR reanalysis over the Southern Ocean and Antarctica. J. Climate, 13, 39403952.

Hoskins, B. J., and T. Ambrizzi, 1993: Rossby wave propagation on a realistic longitudinally varying flow. J. Atmos. Sci., 50, 1661-1671.

Jury, M. R., 1996: Regional teleconnection patterns associated with summer rainfall over South Africa, Namibia and Zimbabwe. Int. J. Climatol., 16, 135-153.

Karoly, D. J., 1989: Southern Hemisphere circulation features associated with El Niño-Southern Oscillation events. J. Climate, 2, 1239-1252.

Kistler, R., and Coauthors, 2001: The NCEP-NCAR 50-Year Reanalysis: Monthly means CD-ROM and documentation. Bull. Amer. Meteor. Soc., 82, 247-267.

Kuhnel, I., 1989: Tropical-extratropical cloudband climatology. Int. J. Climatol., 9, 441-463.

Landman, W. A., and S. J. Mason, 1999: Change in the association between Indian Ocean sea-surface temperatures and summer rainfall over South Africa and Namibia. Int. J. Climatol., 19, 1477-1492.

Latif, M., D. Dommenget, M. Dima, and A. Grötzner, 1999: The role of Indian Ocean sea surface temperature in forcing East African rainfall anomalies during December-January 1997/ 98. J. Climate, 12, 3497-3504.

Lindesay, J. A., and C. H. Vogel, 1990: Historical evidence for Southern Oscillation-southern African rainfall relationships. Int. J. Climatol., 10, 679-689.
_ M. S. J. Harrison, and M. P. Haffner, 1986: The Southern Oscillation and South African rainfall. S. Afr. J. Sci., 82, 196198.

Loschnigg, J., G. A. Meehl, P. J. Webster, J. M. Arblaster, and G. P. Compo, 2003: The Asian monsoon, the tropospheric biennial oscillation, and the Indian Ocean zonal mode in the NCAR CSM. J. Climate, 16, 1617-1642.

Mason, S. J., 1995: Sea-surface temperature-South African rainfall associations, 1910-1989. Int. J. Climatol., 15, 119-135.

— , and M. R. Jury, 1997: Climatic variability and change over southern Africa: A reflection on underlying processes. Prog. Phys. Geogr., 21, 23-50.

— , and P. D. Tyson, 2000: The occurrence and predictability of droughts over southern Africa. Drought: A Global Assessment, D. A. Wilhite, Ed., Vol. II, Routledge, 113-134.

- and L. Goddard, 2001: Probabilistic precipitation anomalies associated with ENSO. Bull. Amer. Meteor. Soc., 82, 619-638.

,-- , N. E. Graham, E. Yulaeva, L. Sun, and P. A. Arkin, 1999: The IRI seasonal climate prediction system and the 1997/98 El Niño event. Bull. Amer. Meteor. Soc., 80, 18531873.

Matarira, C. H., 1990: Drought over Zimbabwe in a regional and global context. Int. J. Climatol., 10, 609-625.

Mo, K. C., 2000: Relationships between low-frequency variability in the Southern Hemisphere and sea surface temperature anomalies. J. Climate, 13, 3599-3610.

— , and M. Ghil, 1987: Statistics and dynamics of persistent anomalies. J. Atmos. Sci., 44, 877-901.

, and J. N. Paegle, 2001: The Pacific-South American modes and their downstream effects. Int. J. Climatol., 21, 1211-1229.

Moron, V., S. Bigot, and P. Roucou, 1995: Rainfall variability in subequatorial America and Africa and relationships with the main sea-surface temperature modes (1950-1990). Int. J. Climatol., 15, 1297-1322.

New, M., M. Hulme, and P. Jones, 1999: Representing twentiethcentury space-time climate variability. Part I: Development of a 1961-90 mean monthly terrestrial climatology. J. Climate, 12, 829-856.

- — - and — -2000 : Representing twentieth-century space-time climate variability. Part II: Development of 190196 monthly grids of terrestrial surface climate. J. Climate, 13, 2217-2238.

— M. Modd, M. Hulme, and P. D. Jones, 2001: Precipitation measurements and trends in the Twentieth Century. Int. J. Climatol., 21, 1899-1922.

Nicholson, S. E., and D. Entekhabi, 1987: Rainfall variability in equatorial and southern Africa: Relationships with sea surface temperatures along the southwestern coast of Africa. J. Climate Appl. Meteor., 26, 561-578.

Palmer, T. N., and Coauthors, 2004: Development of a European Multimodel Ensemble System for Seasonal-to-Interannual Prediction (DEMETER). Bull. Amer. Meteor. Soc., 85, 853872.

Rasmusson, E. M., and T. H. Carpenter, 1982: Variations in tropical sea surface temperature and surface wind fields associated with the Southern Oscillation/El Niño. Mon. Wea. Rev., 110, 354-384.

Reason, C. J. C., 2002: Sensitivity of the southern African circulation to dipole sea-surface temperature patterns in the South Indian Ocean. Int. J. Climatol., 22, 377-393.

, and H. Mulenga, 1999: Relationships between South African rainfall and SST anomalies in the southwest Indian Ocean. Int. J. Climatol., 19, 1651-1673. 
and D. Jagadheesha, 2005: A model investigation of recent ENSO impacts over southern Africa. Meteor. Atmos. Phys., 89, 181-205.

—, R. J. Allan, J. A. Lindesay, and T. J. Ansell, 2000: ENSO and climatic signals across the Indian Ocean basin in the global context: Part I, interannual composite patterns. Int. J. Climatol., 20, 1285-1327.

Richard, Y., N. Fauchereau, I. Poccard, M. Rouault, and S. Trzaska, 2001: 20th century droughts in Southern Africa: Spatial and temporal variability, teleconnections with oceanic and atmospheric conditions. Int. J. Climatol., 21, 873-885.

Rocha, A., and I. Simmonds, 1997a: Interannual variability of south-eastern African summer rainfall. Part I: Relationships with air-sea interaction processes. Int. J. Climatol., 17, 235265.

$\longrightarrow$, and $-1997 \mathrm{~b}$ : Interannual variability of south-eastern African summer rainfall. Part II: Modeling the impact of seasurface temperatures on rainfall and circulation. Int. J. Climatol., 17, 267-290.

Ropelewski, C. F., and M. S. Halpert, 1987: Global and regional scale precipitation and temperature patterns associated with El Niño-Southern Oscillation. Mon. Wea. Rev., 115, 16061626.

Rouault, M., and Y. Richard, 2003: Intensity and spatial extension of drought in South Africa at different time scales. Water $S A$, 29, 489-500.

—, P. Florenchie, N. Fauchereau, and C. J. C. Reason, 2003: South east tropical Atlantic warm events and southern African rainfall. Geophys. Res. Lett., 30, 8009, doi:10.1029/ 2002 GL014840.

Saji, N. H., and T. Yamagata, 2003: Structure of SST and surface wind variability during Indian Ocean dipole mode events: COADS observations. J. Climate, 16, 2735-2751.

—, B. N. Goswami, P. N. Vinayachandran, and T. Yamagata,
1999: A dipole mode in the tropical Indian Ocean. Nature, 401, 360-363.

Smith, T. M., and R. W. Reynolds, 2003: Extended reconstruction of global sea surface temperatures based on COADS data (1854-1997). J. Climate, 16, 1495-1510.

Sobel, A. H., I. M. Held, and C. S. Bretherton, 2002: The ENSO signal in tropical tropospheric temperature. J. Climate, 15, 2702-2706.

Su, H., J. D. Neelin, and C. Chou, 2001: Tropical teleconnection and local response to SST anomalies during the 1997-98 El Niño. J. Geophys. Res., 106D, 20 025-20 044.

Todd, M., and R. Washington, 1999: Circulation anomalies associated with tropical-temperate troughs in southern Africa and the southwest Indian Ocean. Climate Dyn., 15, 937-951.

Trenberth, K. E., 1980: Planetary waves at $500 \mathrm{mb}$ in the Southern Hemisphere. Mon. Wea. Rev., 108, 1378-1389.

— moisture and hydrologic cycle in the NCEP/NCAR reanalyses. Climate Dyn., 14, 213-231.

Tyson, P. D., 1981: Atmospheric circulation variations and the occurrence of extended wet and dry spells over southern Africa. J. Climatol., 1, 115-130.

Walker, N. D., 1990: Links between South African summer rainfall and temperature variability of the Agulhas and Benguela system. J. Geophys. Res., 95, 3297-3319.

Webster, P. J., A. M. Moore, J. P. Loschnigg, and R. R. Leben, 1999: Coupled ocean-atmosphere dynamics in the Indian Ocean during 1997-98. Nature, 401, 356-360.

Xie, P., and P. A. Arkin, 1996: Analysis of global monthly precipitation using gauge observations, satellite estimates, and numerical model predictions. J. Climate, 9, 840-858.

Xie, S.-P., H. Annamalai, F. A. Schott, and J. P. McCreary Jr., 2002: Structure and mechanisms of south Indian Ocean climate variability. J. Climate, 15, 864-878. 